\title{
Characterization and Speciation Modelling of Cyanide in Effluent from an Active Slimes Dam
}

\author{
Elisee N. Bakatula and Hlanganani Tutu* \\ Molecular Science Institute, School of Chemistry, University of the Witwatersrand, Private Bag X3, WITS 2050, Johannesburg, South Africa.
}

Received 20 July 2015, revised 9 March 2016, accepted 24 May 2016.

\begin{abstract}
The utilization of cyanide in the process of gold extraction is an environmental concern as this pollutant is discharged with the tailings. The distribution and fate of cyanide in the environment upon release from the tailings dumps depends on its physical-chemical speciation. The present study was conducted to assess the presence of cyanide species in drainage water from an active slimes dam that receives effluent from a gold reprocessing plant in the Central Rand goldfield (south of Johannesburg, South Africa). Water samples were collected from decant pipes draining water from the top of the slimes dam as well as from a solution trench constructed around the dam. Efflorescent salt crusts and algae were also sampled along the solution trench to assess the extent of cyanide contamination and its promulgation from the slimes. Water samples presented varying chemistry with samples collected from the pipes recording low $\mathrm{pH}$ (between 2 and 4 ) with concentrations of weak acid dissociable cyanide $\left(\mathrm{CN}_{\text {WAD }}\right)$ varying between $5.635 \mathrm{mg} \mathrm{L}^{-1}$ and $8.525 \mathrm{mg} \mathrm{L}^{-1}$. Water samples from the trench were less acidic ( $\mathrm{pH}$ ranged between 5 and 7) with an average concentration of $\mathrm{CN}_{\mathrm{WAD}}$ of $21.72 \mathrm{mg} \mathrm{L}^{-1}$. These values are far greater than the limit of $0.50 \mathrm{mg} \mathrm{L} \mathrm{L}^{-1} \mathrm{set}$ by the authorities through the 'Best Practice guidelines' for any effluent exiting a metallurgical treatment facility. Copper and iron cyanide complexes were the most abundant cyanide complexes in the water samples. The $\mathrm{pH}$ and conductivity of the solution prepared by the dissolution of the salt crusts $\left(10 \mathrm{~g}\right.$ in $50 \mathrm{~mL}$ of deionized water) were 3.44 and $1.611 \mathrm{mScm}^{-1}$, respectively. High concentrations (198.4 $\left.\mathrm{mg} \mathrm{kg}^{-1}\right)$ of $\mathrm{CN}_{\mathrm{T}}$ were obtained in the crusts and these were predominantly strong acid dissociable cyanides $\left(\mathrm{CN}_{\mathrm{SAD}}\right)$ of Fe and Co. The presence of iron cyanides was evident from the bluish-green crusts (Prussian blue) observed around the site, indicating the extent of cyanide contamination. A very low $\mathrm{pH}(2.39)$ was recorded for the algae, with elevated concentrations of $\mathrm{SCN}^{-}$and $\mathrm{OCN}^{-}$that are byproducts of chemical conversion of cyanide. The Visual MINTEQ geochemical modelling code was used to complement the analytical methods in characterizing the speciation of cyanide. The simulations predicted the presence of the following metal-cyanide complexes in water samples as well as in the solid materials: $\mathrm{Fe}(\mathrm{CN})_{6}{ }^{3-}, \mathrm{Fe}(\mathrm{CN})_{6}(\mathrm{aq}), \mathrm{NaFe}(\mathrm{CN})_{6}{ }^{2-}$, $\mathrm{KFe}(\mathrm{CN})_{6}{ }^{2-}, \mathrm{Ni}(\mathrm{CN})_{4}{ }^{2-}, \mathrm{Zn}(\mathrm{CN})_{4}{ }^{2-}, \mathrm{CaFe}(\mathrm{CN})_{6}{ }^{-}, \mathrm{NiH}(\mathrm{CN})_{4}{ }^{-}$and $\mathrm{NiH}_{3}(\mathrm{CN})_{4}{ }^{+}$. This study revealed that cyanide remains persistent in its immediate environment following its release from slimes dams, an issue of concern as some residential areas have developed in the proximity of such facilities. The major highlight of this work has been the comprehensive characterization of cyanide speciation by using geochemical modelling to complement analytical techniques. This is important in understanding the potential risk posed by this pollutant.
\end{abstract}

KEYWORDS

Cyanides, slimes dam, metal cyanide complexes, salt crusts, speciation modelling.

\section{Introduction}

Gold mining waste is estimated to account for 221 million tons or $47 \%$ of all mineral waste produced in South Africa, making it the largest single source of waste and pollution. ${ }^{1}$ Much of this waste is deposited in tailings dams, of which there are more than 270 in the Witwatersrand Basin with most of these tailings (103 tailings) being in the Central Rand gold field. ${ }^{1,2,3}$ Due to inadequate design, poor management and neglect, most of the tailings are subjected to varying degrees of water and wind erosion. ${ }^{4}$ As such they are a source of dust and contribute significantly to the pollution of soil and water.

In the last two decades, many of these dumps have been and are being retreated to recover the remaining gold and the resulting tailings are pumped to disposal sites commonly called slimes dams or tailings storage facilities (TSFs). The late 1970s and early 1980s saw the commencement of major mine tailings reclamation operations initially on the East Rand, at Anglo Gold's ERGO

* To whom correspondence should be addressed. E-mail: hlanganani.tutu @ wits.ac.za reduction facility. Reprocessed waste was deposited on a new mega-dump, south of Springs. In 1981, Rand Mines Crown Gold operations commenced similar operations in the Central Witwatersrand area. The re-processed material was deposited on three large slimes dams near Nasrec and Diepkloof, Soweto. The cleared areas were then developed into industrial and commercial parks, close to the Johannesburg central business district.

Pollution arising from slimes dams, which are repositories for tailings generated from gold extraction, was of concern to communities situated in their vicinity. Apart from wind-blown dust pollution that characterizes mine sites, soil and water contamination, unstable slopes on dumps, use of explosives, and the presence of radioactive materials are other sources of concern in the Witwatersrand area. ${ }^{3,4}$

Over the past 20 years, attention has been given to the impacts on health and the environment implications of chemical contaminants. In South Africa, the Department of Minerals Resources 
(DMR) in cooperation with the Department of Environmental Affairs (DEA) and the Department of Water and Sanitation (DWS) monitor and regulate the mining industry with respect to environmental pollution matters. ${ }^{5}$

The metallurgical process involving gold extraction usually uses $\mathrm{NaCN}$ and $\mathrm{KCN}$ or a combination thereof. The resulting tailings slurry (50\% solids, $50 \%$ water) is pumped and hydraulically deposited in tailings dams.

Tailings dams can cause a number of short- and long-term environmental effects if they are not well designed and managed. These problems relate to surface and groundwater contamination and long-term management associated with poor rehabilitation, tailings dam failure and potential damage that can be caused by natural hazards such as weather events. ${ }^{6}$ Cyanide-containing tailings dams make it possible for cyanide to come into contact with mineral residues, allowing the formation of cyano-species such as thiocyanate, cyanate, weak acid dissociable $\left(\mathrm{CN}_{\text {WAD }}\right)$ and strong acid dissociable $\left(\mathrm{CN}_{\mathrm{SAD}}\right)$ complexes of varying solubility. These reactions may facilitate further distribution and transportation of cyanide in the environment. ${ }^{7}$

Cyanide is very reactive and forms salts with alkali earth cations and ionic complexes of different strengths with a number of metal cations. ${ }^{8}$ The stability of cyanide salts depends on the $\mathrm{pH}$ of the solution and the cation. The salts of sodium, calcium and potassium are soluble in water and readily react to form free cyanide, $\mathrm{CN}_{\text {free }}$ (highly toxic). Complexes of cyanide with $\mathrm{Cu}, \mathrm{Zn}$ and $\mathrm{Cd}$ are relatively weak and are classified as weak-acid dissociable $\left(\mathrm{CN}_{\mathrm{WAD}}\right)$. Even though cyanide complexes with these metals are less toxic compared to free cyanide, their dissociation can release $\mathrm{CN}_{\text {free }}$ and metal ions. Most of the surface water has a neutral $\mathrm{pH}$ of 7 and can to some extent dissociate $\mathrm{CN}_{\mathrm{WAD}} \cdot{ }^{9}$ The $\mathrm{CN}_{\mathrm{SAD}}$ for metals such as $\mathrm{Fe}, \mathrm{Co}, \mathrm{Ag}$ and $\mathrm{Au}$, are dissociable only under extremely acidic conditions. ${ }^{10}$

According to the 'Best Practice' guidelines (the Codes), the amount of cyanide in effluent discharging from a metallurgical treatment facility should not exceed $0.50 \mathrm{mg} \mathrm{L}^{-1}$, except where the discharged solution is returned to the metallurgical process. This limit was stipulated based on potential impacts on human beings, general terrestrial life (ranging from birds to game or livestock) and aquatic life..$^{11,12}$

Some studies have shown that solid waste remaining after the re-processing of the tailings dams generally contains significant concentrations of various pollutants including cyanide. ${ }^{10,13,14,15,16,17}$ Some in the gold mining industry have disputed this, suggesting rather that the cyanide degrades within the tailings and poses no further threat to the environment. The present study aimed to identify and quantify the different cyanide species discharged from gold reprocessing plants into tailings dams and the likelihood of its release into the environment.

\section{Materials and Methods}

\subsection{Site Description}

The studied active tailings dam is located in Nasrec, south of Johannesburg $\left(26^{\circ} 13^{\prime} 42.26^{\prime \prime} \mathrm{S} 27^{\circ} 58^{\prime} 16.64^{\prime \prime} \mathrm{E}\right)$. This slimes dam receives effluent discharged from the reprocessing of smaller gold dumps around the Central Rand goldfield (south of Johannesburg). By definition, an active slimes dam is a tailings waste dump or impoundment onto which deposition of slurry effluent from reprocessing plants is occurring. Reprocessing is a common secondary mining activity in which tailings from old mine dumps are leached with cyanide to salvage the gold left over in them. It is the waste from this reprocessing activity that is dispatched to active slimes dams.
The Crown Gold Recoveries on the Central Rand goldfield operates three gold plants that re-treat old mine waste and slimes dams to recover gold left behind by the original mining operations. The slimes dams, namely Diepkloof, Mooifontein and Nasrec, are $500 \mathrm{~m}$ to $600 \mathrm{~m}$ from one another and are located close to Soweto and Riverlea, both of which are high-density areas (Fig. 1A). A national road (N1) runs through the three tailings dams. The three sites are also close to natural streams and a national football stadium (Soccer City).

\subsection{Sampling and Field Measurements}

Water samples were collected from pipes (or penstocks) draining from the top of the slimes dam as well as from a solution trench in which water from the pipes and seepage points collects and flows to a water retain dam (Fig. 1B) located at the foot of the slimes dam. Water from the retain dam is usually pumped back to the plant for re-use, but in most cases, it overspills and finds its way into natural streams. Sampling was done according to the sampling standard protocols. . $^{18,19,20}$

Water samples (labelled as C) were collected into acid-washed $1 \mathrm{~L}$ polypropylene bottles which were wrapped in black plastic bags to prevent direct exposure of the samples to light and stored in the refrigerator at $4{ }^{\circ} \mathrm{C}$ prior to analysis.

Green algae along the solution trench were collected. The algae were wet at the time of sampling, signifying saturation of algal biomass with the water solution. Solid materials (labelled as $\mathrm{M}_{1}$ ) including bluish-green efflorescent crusts (salt crusts) and tailings from the banks of the solution trench were sampled and kept in a black zip lock plastic bag.

Field parameters (temperature, $\mathrm{pH}$, redox potential (Eh) and electrical conductivity (EC)) were measured using a portable kit (Multi Line F/Set 3, WTW, Germany), equipped with a pH electrode, an integrated temperature probe (SenTix 41), a standard conductivity cell (Tetra Con 375) and an oxidation-reduction potential probe (SenTix ORP), according to standard procedures. ${ }^{18}$

\subsection{Preliminary Treatment and Preparation of Samples}

\subsubsection{Water Samples}

About $0.1 \mathrm{~g}$ of sodium thiosulphate $\left(\mathrm{Na}_{2} \mathrm{~S}_{2} \mathrm{O}_{3}\right)$ was added to each sample to prevent oxidizing species such as $\mathrm{Cl}^{-}$from decomposing the cyanide. Thereafter, $0.1 \mathrm{~g}$ of lead carbonate $\left(\mathrm{Pb}\left(\mathrm{CO}_{3}\right)_{2}\right)$ was added to eliminate the oxidizing effect of $\mathrm{S}^{2-}$ as this would lead to conversion of $\mathrm{CN}^{-}$to $\mathrm{SCN}^{-}$. Finally, the $\mathrm{pH}$ of the samples was raised to above 12 by addition of $\mathrm{NaOH}$ solution to prevent dissociation of complexes and volatilization of cyanide in the form of HCN gas. ${ }^{21}$

Two samples were prepared from each water sample collected for analysis of free cyanide $\left(\mathrm{CN}_{\text {free }}\right)$. One of the samples was filtered and the other was left unfiltered. This was done so as to approximate the amount of $\mathrm{CN}_{\text {free }}$ adsorbed onto colloids and that in solution. Thereafter, from the remaining samples (i.e. surface water), a further two samples were prepared from each. One of these samples was acidified with $1 \mathrm{M} \mathrm{HNO}_{3}$ to $\mathrm{pH} 2$ for the measurement of metals present. The $\mathrm{pH}$ of the other sample was maintained at $\mathrm{pH} 12$ for the measurement of total cyanide $\left(\mathrm{CN}_{\mathrm{T}}\right)$ and cyanide complexes.

From the filtered samples, two samples were prepared; the $\mathrm{pH}$ of the first aliquot was raised to 12 for the determination of $\mathrm{CN}_{\text {free }}$ and the untreated aliquot was used for the analysis of anions.

\subsubsection{Salt Crusts and Algae}

The salt crusts were dried in an oven at $40{ }^{\circ} \mathrm{C}$, cooled in a dessicator, weighed out and dissolved in deionized water (ratio 

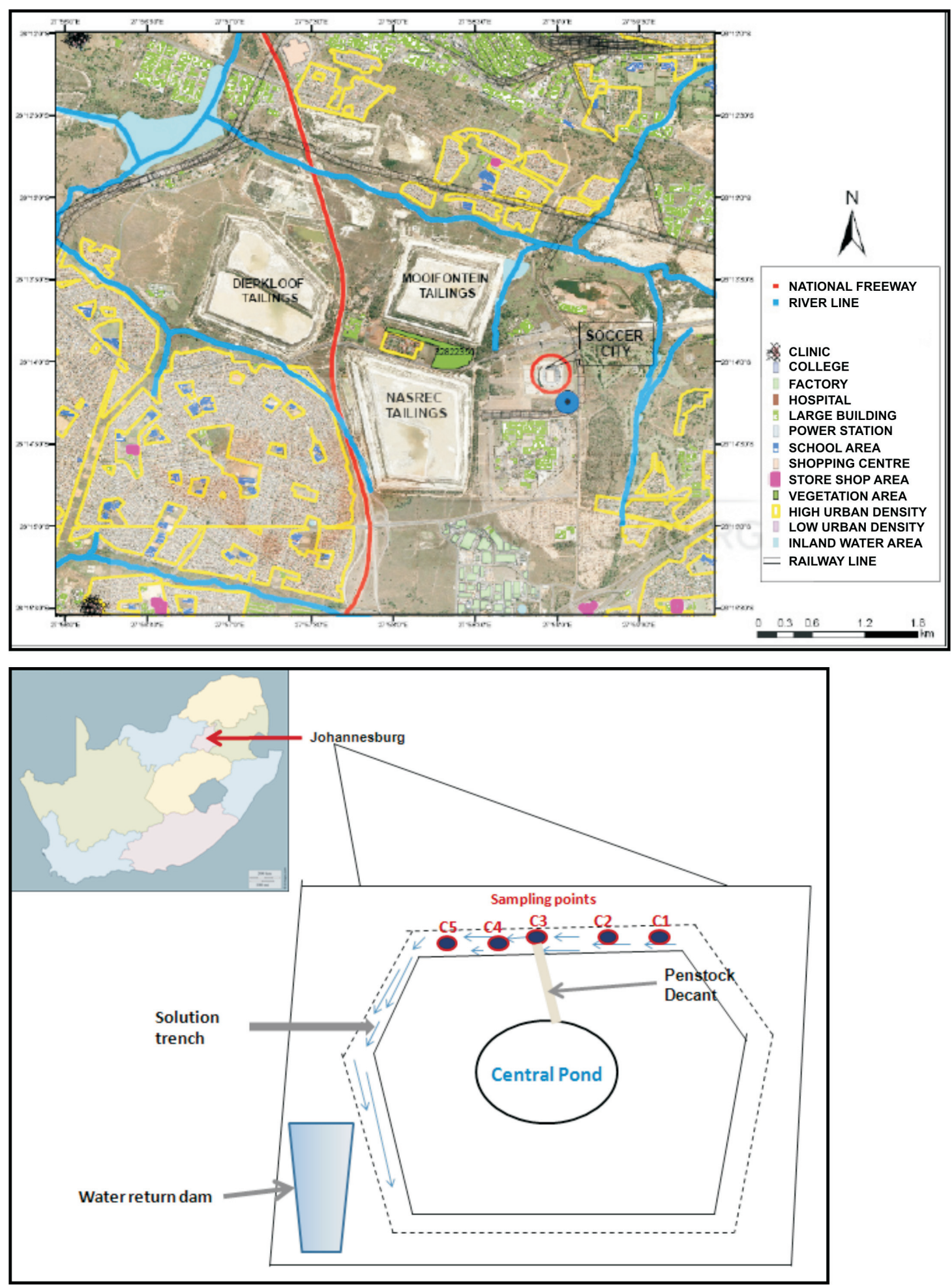

Figure 1 (A) Location of the three active slimes dams (Source: QuickBird, 2001: QuickBird High Resolution Satellite Images, DigitalGlobe, Longmont, CO). (B) Sketch of slimes dam showing the sampling points.

of $1 \mathrm{~g}: 50 \mathrm{~mL}$ ). The solutions were filtered (using the $0.45 \mu \mathrm{m}$ filter paper) to remove sediment residue. The solutions were then subjected to similar treatment as the water samples mentioned above for the analysis of anions $\left(\mathrm{Cl}^{-}, \mathrm{S}_{2} \mathrm{O}_{3}^{2-}\right.$ and $\left.\mathrm{SO}_{4}^{2-}\right)$; primary and secondary cyanide species $\left(\mathrm{CN}_{\text {free, }}, \mathrm{CN}_{\mathrm{T}}, \mathrm{CN}_{\mathrm{WAD}}, \mathrm{CNO}^{-}\right.$, $\left.\mathrm{SCN}^{-}\right), \mathrm{NH}_{4}{ }^{+}$and metals (Fe, $\mathrm{Co}, \mathrm{Cu}, \mathrm{Zn}, \mathrm{Na}, \mathrm{K}, \mathrm{Ca}$ ).

The algae samples were freeze-dried and then ground to fine particles using agate mortars. The samples were stored in plastic bags, marked and prepared for analysis (by dissolution in concentrated nitric acid).

\subsection{Analytical Methods}

Water samples, salt crusts and algae were analyzed for $\mathrm{CN}_{\text {free }}$ $\mathrm{CN}_{\mathrm{T}}, \mathrm{CN}_{\mathrm{WAD}}, \mathrm{CNO}^{-}$and $\mathrm{SCN}^{-}$according to standard methods. ${ }^{21}$ Metal-cyanide complexes were determined by reversed-phase ion interaction high performance liquid chromatography with UV detection as described by Haddad and Kalambaheti. ${ }^{22}$ The $\mathrm{SO}_{4}^{2-}, \mathrm{Cl}^{-}$and $\mathrm{NH}_{4}^{+}$ions were determined by ion chromatography (Metrohm 761 Compact Ion Chromatograph, Switzerland). Thiosulphates $\left(\mathrm{S}_{2} \mathrm{O}_{3}^{2-}\right)$ were determined by ultraviolet visible (UV) spectroscopy ${ }^{23}$ while metals were determined by induc- 
tively coupled plasma-optical emission spectroscopy (ICP-OES) (Spectro Genesis, Kleve, Germany).

\subsection{Optimization and Quality Control}

A certified reference material (CRM) of sediment (RTC015-050) was analyzed in order to validate the analytical methods used. The CRM was prepared in triplicate following the abovementioned sample preparation procedures. Blanks were also prepared in the same way to verify if any contamination occurred during sample preparation and/or analysis.

The precision and accuracy obtained were within the certified ranges with relative standard deviations (RSD) below $10 \%$ and a percentage recovery of $98.5 \%$.

\subsection{Modelling of Cyanide Speciation}

Speciation modelling was performed using the Visual MINTEQ (U.S. EPA) geochemical modelling code that calculates species dominance based on thermodynamic equilibrium. The input data consisted of concentrations of $\mathrm{CN}_{\mathrm{T}}, \mathrm{CNO}^{-}, \mathrm{SCN}^{-}$, anions, metal concentrations and field parameters (EC, Eh, temperature and $\mathrm{pH}$ ).

\section{Results and Discussion}

\subsection{Physical and Chemical Characteristics}

The results obtained for the physical-chemical characteristics of the studied samples are presented in Table 1.

The water sample from the metal pipe $\left(\mathrm{C}_{2}\right)$ was brownish and visibly different from water samples from the plastic pipes. It had a low $\mathrm{pH}$ of 2.14 compared to that for $\mathrm{C}_{1}$ that had a $\mathrm{pH}$ of 4.28. The brownish colour was due to the corrosion of the pipe and dissolution of the constituent iron. This explains the high concentration of Fe recorded in this sample. The high Eh of $648 \mathrm{mV}$ recorded for $\mathrm{C}_{2}$ is likely to have contributed to the oxidation of $\mathrm{Fe}$ according to the following reaction:

$$
4 \mathrm{Fe}^{3+}+12 \mathrm{H}_{2} \mathrm{O} \rightarrow 4 \mathrm{Fe}(\mathrm{OH})_{3} \downarrow+12 \mathrm{H}^{+}
$$

In the above reaction, $\mathrm{Fe}^{3+}$ precipitates as a hydroxide, $\mathrm{Fe}(\mathrm{OH})_{3}$, resulting in a decrease of the $\mathrm{pH}$. A high EC of $9.31 \mathrm{mScm}^{-1}$ was recorded for this sample, largely as a result of the low $\mathrm{pH}$ and high dissolved metal and sulphate ions.

The water samples $\mathrm{C}_{3}$ and $\mathrm{C}_{4}$ collected from the trench came from various sources, namely: water draining from the pond of the tailings dam; water spilling from spigots (i.e. from the slurry coming from the reprocessing plant); rainwater flowing down the slope of the tailings dam (samples were collected during the rainy season) and seepage water. The heterogeneity of the chemistry of the trench water was apparent from the $\mathrm{pH}$, Eh and $\mathrm{EC}$ values. The $\mathrm{pH}$ values of the two samples were 7.17 and 5.6, respectively.

The high $\mathrm{pH}$ values of the trench water could be attributed to the dilution effects of water from the pipe, as this water was a mixture of water from different sources as indicated above. The concentrations of pollutants (as well as conductivity values) were also generally low for these samples.

The EC gives a useful measure of the amount of total dissolved salts (TDS) in water and is inversely proportional to $\mathrm{pH}$. In low $\mathrm{pH}$ water samples e.g. $\mathrm{C}_{1}, \mathrm{C}_{2}$ and $\mathrm{C}_{5}$, high relative values of EC (4-10 $\mathrm{mS} \mathrm{cm}^{-1}$ ) were recorded.

The content of sulphates for $\mathrm{C}_{2}$ was $8737 \mathrm{mg} \mathrm{L}^{-1}$ which was higher than that for $\mathrm{C}_{1}\left(5083 \mathrm{mg} \mathrm{L}^{-1}\right)$. The low $\mathrm{pH}$ for $\mathrm{C}_{2}$ correlates with the high concentration of sulphates and thiosulphates (405 $\left.\mathrm{mg} \mathrm{L}^{-1}\right)$.

The results (Table 1) showed elevated concentrations of Fe, Co,

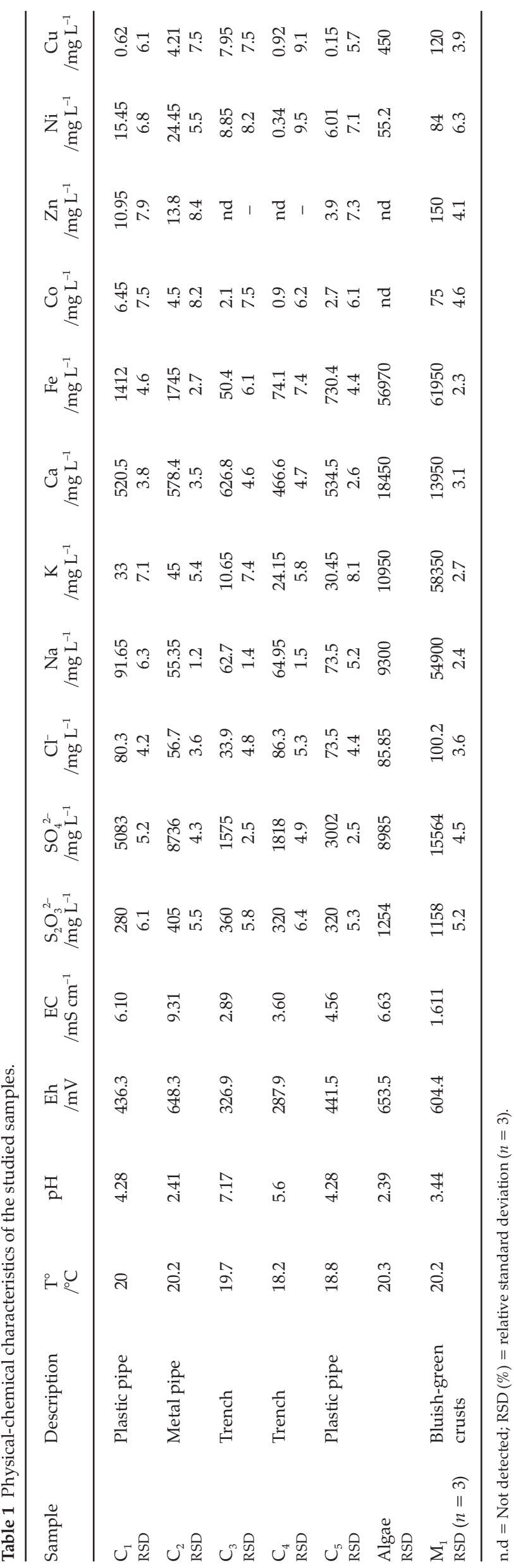


$\mathrm{Zn}, \mathrm{Ni}$ and $\mathrm{Cu}$ in samples $\mathrm{C}_{1}, \mathrm{C}_{2}$ and $\mathrm{C}_{5}$ collected from the pipes that drained water from the pond in the tailings dam. Previous studies $^{13,24}$ showed that the pond collects water flowing from spigots as well as water draining through some of the weathered material along the catena (i.e. between the tailings dam edges and the pond). The high acidity of this water as well as the sulphates content portrayed a similar trend to that observed for the metals. Elevated metal concentrations were found in samples $\mathrm{C}_{1} \mathrm{C}_{2}$ and $\mathrm{C}_{5}$. Iron concentrations were drastically reduced (50.4 and $74.1 \mathrm{mg} \mathrm{L}^{-1}$ ) in water collected from the trench (samples $\mathrm{C}_{3}$ and $\mathrm{C}_{4}$, respectively). This could be attributed to a combination of dilution and precipitation effects.

The elevated $\mathrm{pH}$ of trench water is likely to contribute to precipitation of iron. During the precipitation of $\mathrm{Fe}^{3+}$, colloids are formed that trap metals and co-precipitate them with iron. This could explain the low conductivity values recorded in these samples.

Algae and salts crusts from the solution trench were also analyzed. The $\mathrm{pH}$ of the algae was 2.39 , as low as the one recorded for sample $\mathrm{C}_{2}$. Elevated concentrations of $\mathrm{Fe}$ and $\mathrm{Cu}$ of $56970 \mathrm{mg} \mathrm{kg}^{-1}$ and $450 \mathrm{mg} \mathrm{kg}^{-1}$, respectively, were found in the algae sample. Studies have shown that algae provide a large surface area for adsorption of metals ions and other pollutants. $^{25,26}$

The $\mathrm{pH}$ of the bluish-green crusts was low $\mathrm{pH}$ (3.44) with a high EC. The concentrations of $\mathrm{Fe}, \mathrm{Zn}$ and $\mathrm{Cu}$ were $61950 \mathrm{mg}$ $\mathrm{kg}^{-1}, 150 \mathrm{mg} \mathrm{kg}^{-1}$ and $120 \mathrm{mg} \mathrm{kg}^{-1}$, respectively. The concentration of sulphates in the crusts was $15564 \mathrm{mg} \mathrm{L}^{-1}$ while that for algae was $8985 \mathrm{mg} \mathrm{L}^{-1}$. Sulphates were largely from pyrite oxidation within the slimes dam, but may also have been from gypsum $\left(\mathrm{CaSO}_{4}\right)$ in the crusts. ${ }^{16}$

\subsection{Cyanide Species in Water and Solid Samples}

The concentrations of cyanide species in the samples studied are presented in Table 2 .

Low concentrations of $\mathrm{CN}_{\text {free }}$ were found in water samples (except in $\mathrm{C}_{3}$ ), suggesting a possible loss due to volatilization of cyanide in the form of $\mathrm{HCN}$ gas at low $\mathrm{pH}$.

$\mathrm{CN}_{\text {free }}$ present in the colloids (as seen in Table 2) can be deposited onto the sediments and this would also affect the concentrations of $\mathrm{CN}_{\text {free }}$ and $\mathrm{CN}_{\mathrm{T}}$. The loss of $\mathrm{CN}_{\text {free }}$ is limited in $\mathrm{C}_{3}$ as the $\mathrm{pH}$ is relatively high. A similar trend is expected for the concentrations of cyanide complexes $\left(\mathrm{CN}_{\mathrm{WAD}}\right.$ and $\left.\mathrm{CN}_{\mathrm{SAD}}\right) \cdot \mathrm{CN}_{\mathrm{WAD}}$ complexes tend to dissociate in the $\mathrm{pH}$ range 4.5 to 6 whereas $\mathrm{CN}_{\mathrm{SAD}}$ complexes dissociate below $\mathrm{pH} 2 .{ }^{27}$ These complexes are expected to persist in the sample $\mathrm{C}_{3}$ as the $\mathrm{pH}$ is between 7 and 8 .

High concentrations of cyanates $\left(\mathrm{CNO}^{-}\right)$were found in water samples. $C_{2}$ had a high concentration of cyanate, a product of oxidation of $\mathrm{CN}_{\text {free }}$. This would be expected as this sample had a high Eh $(648 \mathrm{mV})$. Cyanates point to another possible attenuation process, namely, the hydrolysis (Equation 2) and oxidation of $\mathrm{CN}_{\text {free }} \cdot{ }^{28}$

The presence of $\mathrm{NH}_{4}^{+}$further suggests that $\mathrm{CNO}^{-}$can be converted to $\mathrm{NH}_{3}$ (Equation 3) which in turn is converted to $\mathrm{NH}_{4}{ }^{+}$according to (Equation 4$){ }^{27}$

$$
\begin{aligned}
& \mathrm{CN}^{-}+\mathrm{H}_{2} \mathrm{O} \rightarrow \mathrm{CNO}^{-}+2 \mathrm{H}^{+}+2 \mathrm{e}^{-} \\
& \mathrm{CNO}^{-}+2 \mathrm{H}_{2} \mathrm{O} \rightarrow \mathrm{CO}_{2}+\mathrm{NH}_{3}+\mathrm{OH}^{-} \\
& 2 \mathrm{NaCNO}+\mathrm{H}_{2} \mathrm{SO}_{4}+4 \mathrm{H}_{2} \mathrm{O} \rightarrow\left(\mathrm{NH}_{4}\right)_{2} \mathrm{SO}_{4}+2 \mathrm{NaHCO}_{3}
\end{aligned}
$$

The results showed a relatively high concentration of $\mathrm{CN}_{\text {free }}$ in the algae compared to that found in water samples (average ratio algae: water of 1.5:1). Despite the high concentration of $\mathrm{Fe}$, very low concentrations of $\mathrm{CN}_{\mathrm{SAD}}$ were found in algae. This is likely due to the low $\mathrm{pH} 2.39$ as $\mathrm{CN}_{\mathrm{SAD}}$ complexes would dissociate below $\mathrm{pH}$ 2.5. The fate of cyanides in algae is confirmed by the elevated concentrations of $\mathrm{CNO}^{-}$as well as $\mathrm{SCN}^{-}$. The high Eh value would lead to the chemical conversion of cyanides into cyanates. The high concentration of $\mathrm{SCN}^{-}$is likely due to the presence of high concentrations of thiosulphates as shown in Table 2. Thiosulphates are an active sulphur species that degrade cyanide to $\mathrm{SCN}^{-}{ }^{10,29,30}$

Crusts $\left(\mathrm{M}_{1}\right)$ showed elevated concentrations of $\mathrm{CN}_{\mathrm{T}}$ with a predominance of $\mathrm{CN}_{\mathrm{SAD}}$. This could be attributed to the precipitation and/or adsorption of metal-cyanide complexes. Such crusts have been found to contain iron oxyhydroxides ${ }^{31}$ that can adsorb cyanides and its complexes. ${ }^{10}$ The elevated concentrations of $\mathrm{CN}_{\mathrm{SAD}}$ and $\mathrm{Fe}$ and the bluish-green colour of the crusts suggested the presence of Prussian blue. Prussian blue is formed when ferrous cyanide, $\left[\mathrm{Fe}^{\mathrm{II}}(\mathrm{CN})_{6}\right]^{2-}$, reacts with $\mathrm{Fe}^{3+}$ to form a mixed valence complex of $\mathrm{Fe}^{\mathrm{III}} / \mathrm{Fe}^{\mathrm{II}} .{ }^{32}$

$$
4 \mathrm{Fe}^{3+}+3\left[\mathrm{Fe}^{\mathrm{II}}(\mathrm{CN})_{6}\right]^{4-} \rightarrow \mathrm{Fe}^{\mathrm{III}}\left[\mathrm{Fe}^{\mathrm{III}} \mathrm{Fe}^{\mathrm{II}}(\mathrm{CN})_{6}\right]_{3}
$$

Ferrous cyanide is typically contained in high $\mathrm{pH}$ water draining from spigots; while $\mathrm{Fe}^{3+}$ would be dominant in water draining from the pond, at low $\mathrm{pH}$ and high redox potential. Thus, the solution trench acts as a mixing zone for these water types, resulting in moderate to circum-neutral water.

Adsorption of cyanides onto solids was substantiated by assessing adsorption onto colloids, this through comparing cyanide concentrations in filtered and filtered water (Table 3). The results show that up to $34 \%$ of $\mathrm{CN}_{\text {free }}$ was adsorbed onto colloids.

\subsection{Metal-Cyanide Complexes in Water and Solid Samples}

The results obtained for metal-cyanide complexes in water and solids are presented in Figs. 2 and 3.

Table 2 Concentrations of cyanide species and related compounds in water and solid material samples.

\begin{tabular}{lccccccc}
\hline Sample & $\begin{array}{c}\mathrm{CN}_{\text {free }} \\
/ \mathrm{mg} \mathrm{L}^{-1}\end{array}$ & $\begin{array}{c}\mathrm{CN}_{\mathrm{WAD}} \\
/ \mathrm{mg} \mathrm{L}^{-1}\end{array}$ & $\begin{array}{c}\mathrm{CN}_{\mathrm{SAD}} \\
/ \mathrm{mg} \mathrm{L}^{-1}\end{array}$ & $\begin{array}{c}\mathrm{CN}_{\mathrm{T}} \\
/ \mathrm{mg} \mathrm{L}^{-1}\end{array}$ & $\begin{array}{c}\mathrm{SCN}^{-} \\
/ \mathrm{mg} \mathrm{L}^{-}\end{array}$ & $\begin{array}{c}\mathrm{CNO}^{-} \\
/ \mathrm{mg} \mathrm{L}^{-1}\end{array}$ & $\begin{array}{c}\mathrm{NH}_{4}^{+} \\
/ \mathrm{mg} \mathrm{L}^{-1}\end{array}$ \\
\hline $\mathrm{C}_{1}$ & 3.492 & 5.635 & 0.807 & 9.934 & 97.57 & 105.9 & 31.25 \\
$\mathrm{C}_{2}$ & 7.544 & 8.244 & 0.922 & 16.71 & 99.98 & 142.5 & 32.55 \\
$\mathrm{C}_{3}$ & 15.95 & 35.47 & 6.540 & 57.96 & 94.43 & 100.5 & 33.88 \\
$\mathrm{C}_{4}$ & 7.492 & 7.965 & 3.613 & 19.07 & 99.86 & 98.56 & 25.17 \\
$\mathrm{C}_{5}$ & 1.428 & 8.525 & 9.057 & 19.01 & 94.88 & 114.3 & 34.05 \\
Algae & 10.45 & 14.24 & 0.470 & 25.16 & 213.4 & 301.6 & 85.02 \\
M1 & 15.73 & 85.92 & 96.75 & 198.4 & 247.9 & 333.2 & 78.09 \\
LOD & 0.008 & 0.004 & 0.003 & 0.001 & 0.035 & 0.005 & 0.008 \\
MQL & 0.02 & 0.01 & 0.05 & 0.03 & 0.12 & 0.015 & 0.021 \\
\hline
\end{tabular}

Note: $\mathrm{LOD}=$ limit of detection; $\mathrm{MQL}=$ minimum quantifiable level; $n=3$; RSD $<10 \%$. 
Table 3 Adsorption of cyanide onto colloids.

\begin{tabular}{lccc}
\hline Sample & \multicolumn{3}{c}{$\mathrm{CN}_{\text {free }}$} \\
\cline { 2 - 4 } & Non-filtered & Filtered & $\begin{array}{c}\text { Adsorbed onto } \\
\text { colloids } \\
/ \mathrm{mg} \mathrm{L}^{-1}\end{array}$ \\
\hline $\mathrm{mg} \mathrm{L}_{1}$ & $/ \mathrm{mg} \mathrm{L}^{-1}$ & 0.578 \\
$\mathrm{C}_{2}$ & 4.492 & 3.914 & 1.062 \\
$\mathrm{C}_{3}$ & 8.544 & 7.482 & 0.73 \\
$\mathrm{C}_{4}$ & 15.95 & 15.22 & 2.548 \\
$\mathrm{C}_{5}$ & 7.492 & 4.944 & 1.154 \\
\hline
\end{tabular}

Copper and iron cyanide complexes were the most dominant complexes found in the water samples. The field measurements presented in Table 1 showed that the $\mathrm{pH}$ of the water samples was between 2 and 7. At this $\mathrm{pH}$ range, it is expected that dissociation of cyanide complexes, $\mathrm{CN}_{\mathrm{WAD}}$ (up to $\mathrm{pH}$ 6.5) and $\mathrm{CN}_{\mathrm{SAD}}$ (at $\mathrm{pH}$ less than 2.5) will occur. The results showed high concentrations of $\mathrm{Cu}$-cyanide complex in $\mathrm{C}_{4}$. The $\mathrm{Ni}$-cyanide complex was not detected in $\mathrm{C}_{1}$ and $\mathrm{C}_{5}$ whilst relatively high concentrations were obtained for $\mathrm{C}_{2}$ and $\mathrm{C}_{3}$. Cobalt and iron(III) cyanide complexes were not detected in water samples even though their concentrations in the crusts were found to be elevated. $\mathrm{Fe}(\mathrm{II})$-cyanide was the abundant complex in algae while Fe(III)-cyanide was not detected.

\subsection{Modelling of Cyanide Speciation}

The challenge of analysis is that not all constituents can be determined due to inadequacies in the capabilities of analytical instruments. Thus, modelling was conducted as a complementary technique to analytical methods to predict cyanide speciation. The results are presented in Table 4.

The model predicted the presence of strong and weak metal-cyanide complexes such as: $\mathrm{Co}(\mathrm{CN})_{3}{ }^{-}, \mathrm{Co}(\mathrm{CN})_{5}{ }^{3-}$, $\mathrm{Fe}(\mathrm{CN})_{6}{ }_{6}^{3-}, \mathrm{Fe}(\mathrm{CN})_{6}(\mathrm{aq}), \mathrm{KFe}(\mathrm{CN})_{6}{ }^{2-}, \mathrm{Ni}(\mathrm{CN})_{4}{ }^{2-}, \mathrm{Zn}(\mathrm{CN})_{4}{ }^{2-}$, $\mathrm{CaFe}(\mathrm{CN})_{6}{ }_{6}^{-}$and $\mathrm{NiH}(\mathrm{CN})_{4}{ }_{4}^{-}$and $\mathrm{NiH}_{3}(\mathrm{CN})_{4}{ }^{+}$in the water samples The existence of double cyanide salts, namely: $\mathrm{NaFe}(\mathrm{CN})_{6}^{3-}$, $\mathrm{KFe}(\mathrm{CN})_{6}^{2-}$ and $\mathrm{CaFe}(\mathrm{CN})_{6}{ }^{-}$were also depicted by the model.

The solid materials (a mixture of tailings and salt crusts) were shown to have a variety of minerals, e.g. goethite $(\mathrm{FeOOH})$, ferrihydrite $\left(\mathrm{Fe}(\mathrm{OH})_{3}\right)$, K-Jarosite $\left(\mathrm{KFe}_{3}\left(\mathrm{SO}_{4}\right)_{2}(\mathrm{OH})\left(\mathrm{H}_{3} \mathrm{O}\right)\right.$, gypsum $\left(\mathrm{CaSO}_{4} \cdot 2 \mathrm{H}_{2} \mathrm{O}\right)$, maghemite $\left(\mathrm{Fe}_{2} \mathrm{O}_{3}\right)$, magnetite $\left(\mathrm{Fe}_{3} \mathrm{O}_{4}\right)$, $\mathrm{Cu}$-cyanide $(\mathrm{Cu}-\mathrm{CN})$, cupric and cuprous-ferrite $\left(\mathrm{CuFeO}_{4}\right)$.

\section{Conclusion}

The study has shown the potential of slimes dams to release cyanide and its by-products into receiving water systems. Drainage from the studied slimes dam was found to be acidic with elevated concentrations of metals and cyanide species. The low $\mathrm{pH}$ largely controls the amount of $\mathrm{CN}_{\text {free }}$ by causing the dissociation of most cyanide complexes (thus releasing $\mathrm{CN}_{\text {free }}$ ) and the reaction of $\mathrm{H}^{+}$with $\mathrm{CN}_{\text {free, }}$, resulting in the volatile and toxic

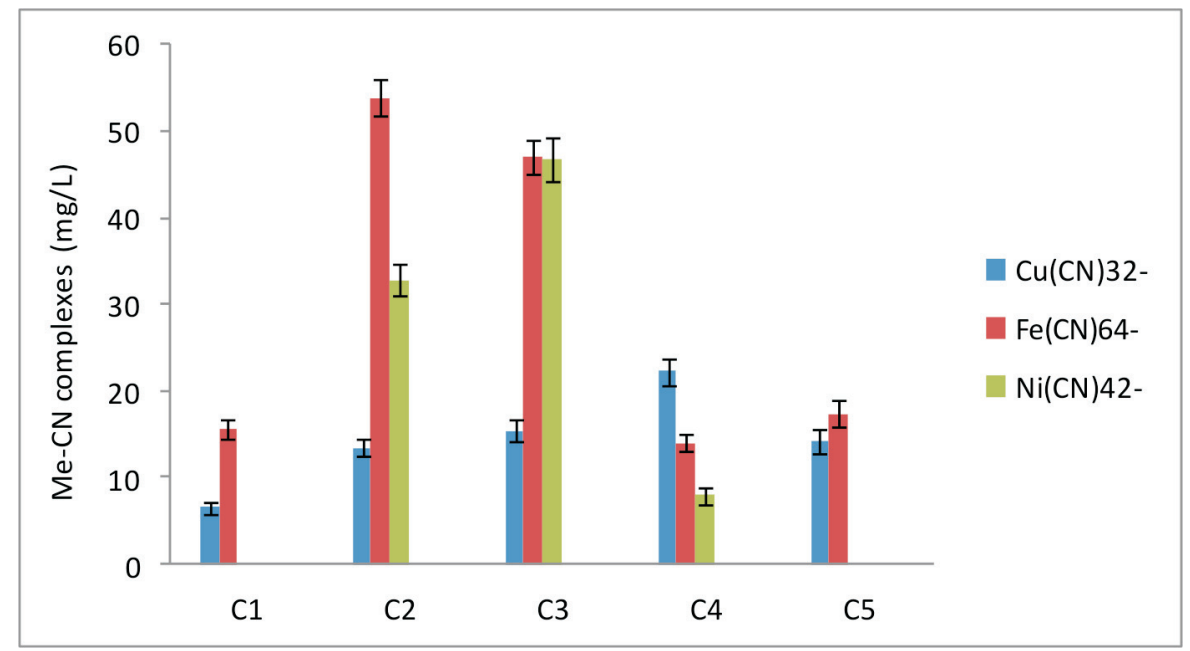

Figure 2 Metal-cyanide complexes in water samples $(n=3$, RSD $<10 \%)$.

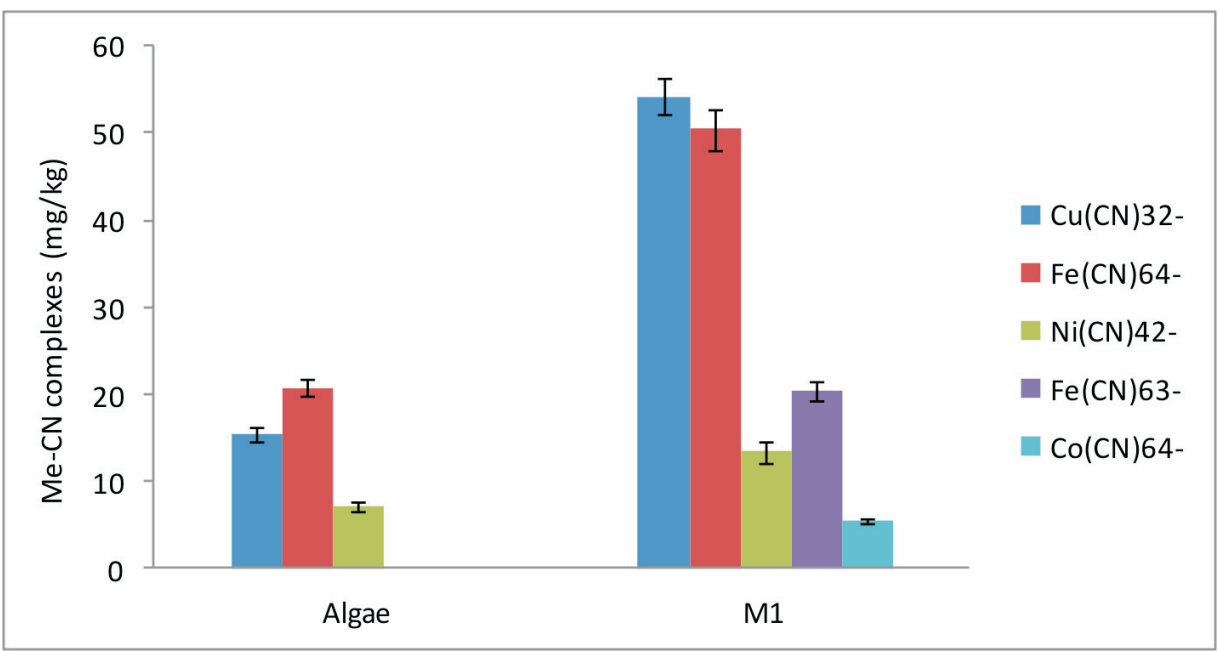

Figure 3 Metal-cyanide complexes in solid materials $(n=3$, RSD $<10 \%)$. 


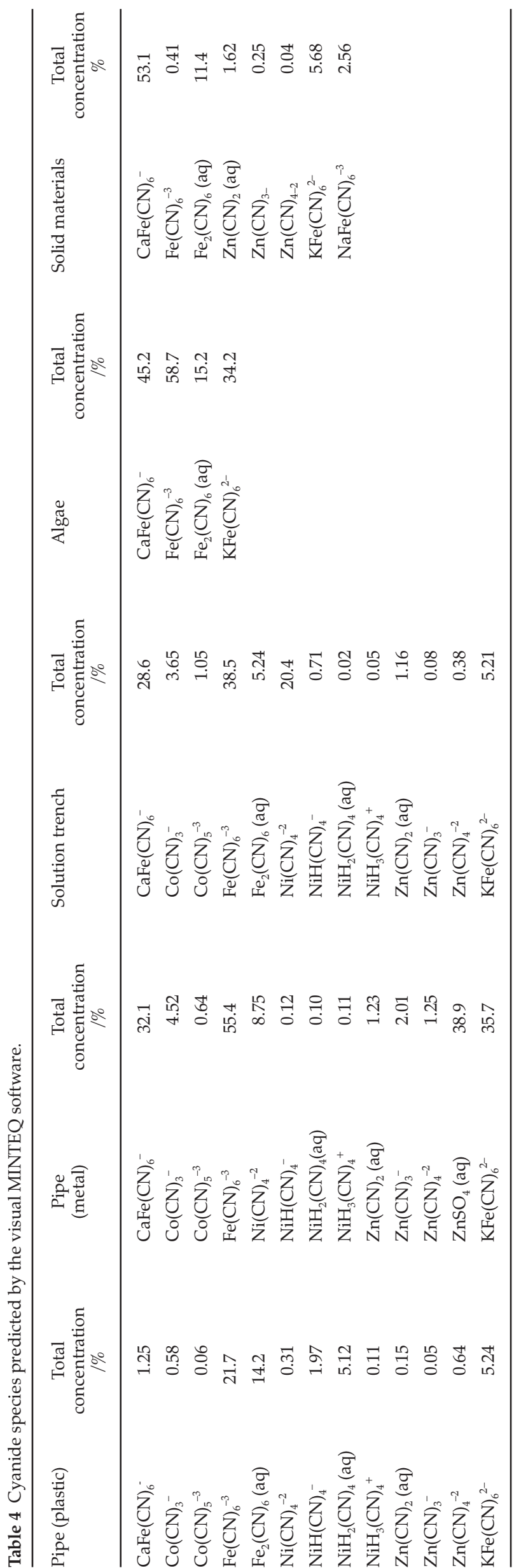

HCN. The different cyanide species and by-products observed pointed to the variability in geochemical processes occurring, notably a mixture of $\mathrm{CN}_{\mathrm{WAD}}$ in moderate to circum-neutral $\mathrm{pH}$ water and $\mathrm{CN}_{\mathrm{SAD}}$ in low $\mathrm{pH}$ water as well as by-products such as $\mathrm{CNO}^{-}, \mathrm{SCN}^{-}$and $\mathrm{NH}_{4}^{+}$.

$\mathrm{Fe}(\mathrm{II})$-cyanide, $\mathrm{Cu}$-cyanide and $\mathrm{Ni}$-cyanide complexes were predominant in water samples. Both $\mathrm{Fe}(\mathrm{II}) /(\mathrm{III})$-cyanide complexes were present in the crusts, evidence of the presence of the Prussian blue. Adsorption of cyanide onto colloids pointed to its tendency to accumulate in solid phases. Speciation modelling, as a complementary technique, predicted the presence of $\mathrm{CN}_{\text {WAD }}$, $\mathrm{CN}_{\mathrm{SAD}}$ and the predominance of double cyanide salts in solids.

The study has managed to characterize the evolution of cyanide following deposition of effluent, dispelling the simplistic assumption that cyanide just degrades and volatilizes out of the tailings. Its distribution and that of its secondary products sheds some light as to the potential risks that this pollutant can pose to the environment.

\section{Acknowledgements}

The authors would like to thank the National Research Foundation and the Carnegie Corporation for the financial support.

\section{References}

1 DWAF, Department of Water Affairs and Forestry, Waste Generation in South Africa, Water Quality Management Series, 2001.

2 AngloGold Ashanti, Woodlands Project-Good Progress Being Made with Phytoremediation Project, Environment-AngloGold Ashanti Report to Society, 2004.

3 J.F. Durand, The impact of gold mining on the Witwatersrand on the rivers and karst system of Gauteng and North West Province, South Africa, J. Afr. Earth Sci., 2012, 68, 24-43.

4 N.F. Mphephu, B. Khumalo, H.J. Anegarn and M.J. Viljoen, Environmental classification of mine tailings of the Central Rand using remote sensing. Proceedings, Mining and Sustainable Development conference, Johannesburg, 2003, Chamber of Mines of South Africa.

5 GDACE, Mining Environmental Impact Guide. Gauteng Department of Agriculture, Conservation and Environment, 2003, Gauteng Provincial Government, Johannesburg.

6 USEPA, Human Health and Environmental Damages from Mining and Mineral Processing Wastes, Office of Solid Waste, United States Environmental Protection Agency, 1998, Washington D.C.

7 E.N. Bakatula, E.M. Cukrowska, L. Chimuka and H. Tutu, Characterization of cyanide in a natural stream impacted by gold mining activities in the Witwatersrand Basin, South Africa, Toxicol. Environ. Chem., 2012, 94(1), 7-19.

8 R.R. Dash, A. Gaur and C. Balomajunder, Cyanide in industrial wastewaters and its removal - a review on biotreatment, J. Hazard Mater., 8482, 11 pp. (In press).

9 The International Cyanide Management Institute (2006), http:// www.cyanidecode.org. 2006

10 G.J. Zagury, K. Oudjehani and L. Deschenes, Characterization and availability of cyanide in solid mine tailings from gold extraction plants, Sc. Total Environ., 2004, 320, 211-24.

11 N.H. Lötter, Cyanide Volatilisation from Gold Leaching Operations and Tailing Storage Facilities, M.Sc. thesis, University of Pretoria, Pretoria, South Africa, 2006.

12 P.W. Lotz, Cyanide management in gold processing, in Proceedings of Waste Management, Emissions and Recycling in the Metallurgical and Chemical Process Industries (F. Petersen, ed.), Mintek, Randburg, 2004,

13 E.N. Bakatula, Cyanide and Cyanide Complexes in the Gold-mine Polluted Land in the East and Central Rand Goldfields, South Africa, M.Sc. thesis, University of the Witwatersrand, Johannesburg, South Africa, 2009.

14 C.A. Young and T.S. Jordan, Cyanide remediation: current and past technologies, in Proceedings of the 10th Annual Conference on Hazardous Waste Research, Great Plains/Rocky Mountain Hazardous Substance Research Center, Kansas State University, Kansas, 1995.

15 A.C. Nengovhela, B. Yibas and J.S. Ogola, Characterisation of gold 
tailings dams of the Witwatersrand Basin with reference to their acid mine drainage potential, Johannesburg, South Africa, Water $S A, 2007$, 32, 499-506.

16 H. Tutu, Mining and Water Pollution, Water Quality Monitoring and Assessment, Dr. Voudouris (Ed.), ISBN 978-953-51-0486-5, InTech, Available from: http://www.intechopen.com/books/water-qualitymonitoring-and-assessment/mining-and-water-pollution, 2012.

17 K. Naicker, E.M. Cukrowska and T.S. McCarthy, Acid mine drainage arising from gold mining activities in Johannesburg, South Africa and environs, Int. J. Environ. Pollut., 2003, 122, 29-40.

18 H.F. Hermond and E.J. Fechner-Levy, Chemical Fate and Transport in the Environment, 2nd edn., Academic Press, San Diego, 2000, 433.

19 C.A.J. Appelo and D. Potsma, Geochemistry, Groundwater and Pollution, 2nd edn., CRC Press, London, 2005.

20 S.S. Embrey and D.L. Runkle, U.S. Geological Survey, Scientific Investigations Report 2006-5290, National Water-Quality Assessment Program - Principal Aquifers, 2006.

21 APHA Standard Methods for the Examination of Water and Wastewater, 20th edn. (L.S. Clesceri, Greenberg A.E. and Eaton, A.D., eds.), American Public Health Association, American Water Works Association and Water Environment Federation, Washington, DC, 1998.

22 P.R. Haddad and C. Kalambaheti, Advances in ion chromatography: speciation of $\mathrm{mL}^{-1}$ levels of metallo-cyanides using ion-interaction chromatography, Anal. Chim. Acta., 1991, 250, 21-36.

$23 \mathrm{~K}$. Tomozo and O. Katsuaki, Separation and spectophotometric determination of thiosulfate, sulfite and sulphide in their mixtures, Anal. Chem., 1992, 8, 285-291.

24 H. Tutu, Determination and Geochemical Modeling of the Dispersal of
Uranium in Gold Mine Polluted Land on the Witwatersrand, Ph.D. thesis, University of the Witwatersrand, Johannesburg, South Africa, 2006.

25 W. Mackie and R.D. Preston, Cell wall and intercellular region polysaccharides, in Algal physiology and biochemistry, (W.D.P. Stewart ed.), Blackwell Scientific Publications, Oxford, UK, 1974, 58-64.

26 E.N. Bakatula, E.M. Cukrowska, L. Chimuka ad H. Tutu, Characterization of cyanide in a natural stream impacted by gold mining activities in the Witwatersrand Basin, South Africa, Toxicol. Environ. Chem., 2012, 94(1), 7-19.

27 A. Dzombak, S. Rajat and M. Wong-Chong, Cyanide in Water and Soil. Chemistry, Risk, and Management, CRC, Taylor \& Francis, New York, 2006.

28 S.A.K. Palmer, M.A. Breton, T.J. Nunno, D.M. Sullivan and N.F. Surprenant, Metal/Cyanide Containing Wastes: Treatment Technologies, Noyes Data Corp., Park Ridge, NJ, 1988.

29 R.G. Luthy and S.G. Bruce, Kinetics of reaction of cyanide and reduced sulphur species in aqueous solution, Environ. Sci. Techn., 1979, 13, 1481.

30 A. Smith and T. Mudder, Chemistry and Treatment of Cyanidation Wastes. Edition Mining Journal Books Ltd., 1991.

31 B.P.C. Camden-Smith and H. Tutu, Geochemical modelling of the evolution and fate of metal pollutants arising from an abandoned gold mine tailings facility in Johannesburg, Water Sci. Technol., 2014, DOI:10.2166/wst.2014.028 (In press).

32 R.S. Ghosh, D. Dzombak, R. Luthy and J. Smith, In situ treatment of cyanide-contaminated groundwater by iron cyanide precipitation, Water Environ. Res., 1999, 71, 1217-1228. 